\title{
Action of AIGaInP laser and high frequency generator in cutaneous wound healing. A comparative study ${ }^{1}$
}

\author{
Rayssilane Cardoso de Sousa ${ }^{\text {I }}$, Antônio Luiz Martins Maia Filho ${ }^{\text {II }}$, Renata Amadei Nicolau ${ }^{\text {III }}$, Lianna Martha Soares Mendes ${ }^{\text {IV }}$, \\ Talvany Luis de Barros ${ }^{\mathrm{v}}$, Silvana Maria Véras Neves ${ }^{\mathrm{VI}}$
}

DOI: http://dx.doi.org/10.1590/S0102-865020150120000001

IFellow Master degree, Postgraduate Program in Materials Engineering, Instituto Federal de Educação, Ciências e Tecnologia (IFSP), Teresina-PI, Brazil. Conception and design of the study, technical procedures, acquisition and interpretation of data, manuscript preparation.

IIPhD, Biomedical Engineering, Universidade do Vale do Paraíba (UNIVAP), Sao Jose dos Campos-SP, Brazil. Macroscopic examinations, interpretation of data.

IIIPhD, Biomedical Engineering, Institute for Research and Development, UNIVAP, Sao Jose dos Campos-SP, Brazil. Statistical analysis.

${ }^{\mathrm{IV}}$ Master, Sciences and Health, Universidade Federal do Piauí (UFPI), Teresina-PI, Brazil. Histopathological examinations, interpretation of data.

${ }^{v}$ Specialist, Higher Education Teaching, Universidade Presbiteriana Mackenzie, Sao Paulo-SP, Brazil. Technical procedures, statistical analysis.

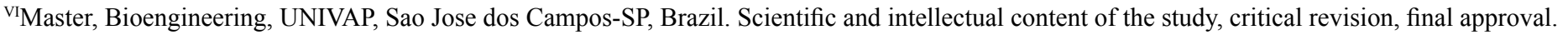

\begin{abstract}
PURPOSE: To evaluate in a macroscopic, histological and histomorphometric manner the healing process of cutaneous wounds in mice.

METHODS: The sample consisted of 40 male mice and was divided in four groups: $1^{\text {st }}$ group (control, $\mathrm{n}=10$ ), $2^{\text {nd }}$ group (High Frequency Generator - HF, the maximum amplitude range, 120s, $\mathrm{n}=10$ ), $3^{\text {rd }}$ group (AlGaInP Laser $660 \mathrm{~nm}, 30 \mathrm{~mW}$ power, $5 \mathrm{~J} / \mathrm{cm}^{2}$, applying scan mode, 120s, $\mathrm{n}=10$ ) and $4^{\text {th }}$ group (AlGaInP Laser $660 \mathrm{~nm}, 30 \mathrm{~mW}$ power, $8 \mathrm{~J} / \mathrm{cm}^{2}$, applying scan mode, $\mathrm{n}=10$ ). The surgical incision was made with an $8 \mathrm{~mm}$ diameter punch perpendicularly to the back of the animal. The statistical analysis was achieved by the statistical test One Way Anova post hoc Tukey Test and significance at $\mathrm{p}<0.05$ in GraphPad Prism program.
\end{abstract}

RESULTS: It was observed that in the acute phase the AlGaInP Laser at $5 \mathrm{~J} / \mathrm{cm}^{2}$ provided a greater stimulus to healing, and both lasers were effective in the remodeling phase.

CONCLUSION: The AlGaInP lasers from $5 \mathrm{~J} / \mathrm{cm}^{2}$ to $8 \mathrm{~J} / \mathrm{cm}^{2}$ showed better biomodulatory results in the acute and remodeling phases respectively, however, the HF was less effective than the laser, providing significant benefits only in the acute phase of tissue repair.

Key words: Wound Healing. Skin. Lasers, Gas. Ozone. Mice. 


\section{Introduction}

The skin is an organ responsible for the interface of communication between the body and the organism and it adapts to perform the most diverse functions ${ }^{1}$, like coating, thermoregulation, secretion and defense. However, some events ${ }^{2}$ can lead to tissue loss and cause wounds, which constitutes a break in the continuity of a corporal tissue ${ }^{3}$, whose causes are: physical, chemical or mechanical traumas among others. In this context, there is stimulation of the organism's defense and the beginning of the cicatrization, which consists in reconstructing the injured site, in order to restore the integrity and normal function ${ }^{4}$, besides being complex and dynamic, and involving biochemical and physiological events, which must act in harmony for the benefit of tissue restoration ${ }^{5,6}$.

However, the complex process of tissue cicatrization can be influenced, it may not occur in a successful manner and it has long been an object of study concerning the factors that affect it. In recent years, researchers have used different equipments to facilitate the healing process of skin wounds with demonstrably scientific results ${ }^{7-10}$. In this context, it refers to the low power laser (LPL), as AlGaInP, the AsGa and HeNe, therapeutic ultrasound, LED (light emitting diode) and the High Frequency Generator (HF) as current resources that, according to the literature, show beneficial and effective action.

In the last years, several studies have shown the benefits of the extensive use of the LPL in situations such as the treatment of soft tissue injuries, joint diseases, open wounds, pressure ulcers, among others ${ }^{11-14}$. The AlGaInP laser $(660 \mathrm{~nm})$ is a therapeutic light of the electromagnetic spectrum in the red line, whose irradiation in injured tissues triggers a series of physiological effects necessary for the process of wound cicatrization and repair at tissue and organic levels by means of the photobiomodulation process, in addition to causing therapeutic effects, such as: local analgesia, edema reduction and anti-inflammatory action ${ }^{11,15}$.

Another relevant resource for the tissue repair process is the HF - product of an alternating current of high frequency and low intensity, widely used in aesthetics. This resource uses ozone as a therapeutic agent, whose potent oxidizing effect stimulates biochemical events during cellular metabolism, besides having antimicrobial, bactericidal and fungicidal effects ${ }^{9,16-18}$.

Studies show that the $\mathrm{LPL}^{7,12,13,19-21}$, as well as $\mathrm{HF}^{9,16}$, accelerate the tissue repair process for wounds, after incisional lesion, being relevant in the treatment of skin disorders, once the
AlGaInP laser reduces the inflammatory reaction and provides better quality and greater speed in the repair process of soft tissue $^{11,15}$, while the HF can intervene in the oxidoreduction balance with germicide, bactericide and antiseptic properties in the cicatrization process $^{9,16}$. Given this, the goal was to have a macroscopic, histological and histomorphometric assessment of the process for cutaneous wound cicatrization in mice, by using AlGaInP Laser therapy compared to treatment with HF.

\section{Methods}

The study was approved by the Animal Ethics Committee - AEC of FACID/DeVry with the protocol No. 029/13, on 12.19.2013, according to the Arouca Federal Law No. 11.974/2008 - Animal Experimentation.

\section{Experimental groups}

The sample was composed by forty male mice (Mus musculus, Muridae Family) with a mean weight between 20 and 30 grams, randomly divided into four groups according to the treatment and subdivided into two groups (A and B), according to the period of observation after the treatment, of seven and 14 days. The experimental groups were:

- Group 1: control $(\mathrm{n}=10)$.

- Group 2: High Frequency Generator - HF (maximum amplitude band, cautery electrode, $120 \mathrm{~s})(\mathrm{n}=10)$.

- Group 3: laser AlGaInP (660nm), applying scan mode, $30 \mathrm{~mW}$ power, $5 \mathrm{~J} / \mathrm{cm}^{2}, 120 \mathrm{~s}(\mathrm{n}=10)$.

- Group 4: laser AlGaInP (660nm), applying scan mode, $30 \mathrm{~mW}$ power, $8 \mathrm{~J} / \mathrm{cm}^{2}, 120 \mathrm{~s}(\mathrm{n}=10)$.

\section{Induction of experimental injury}

The animals were weighed and then anesthetized ${ }^{8}$ with the administration, by intramuscular injection, of ketamine hydrochloride $10 \%$ in dose of $0.1 \mathrm{ml}$ per $100 \mathrm{~g}$ of body weight associated to the same dose of xylazine hydrochloride $2 \%$. The anesthetic drugs were applied independently. The skin wound was induced in the back of the animals, in a dorsal decubitus position, initiated with the trichotomy of the region. To perform the experimental injury a surgical instrument (punch) of $8 \mathrm{~mm}$ in diameter was utilized, perpendicularly positioned to the back, of which the wound depth was corresponding to the epidermis and dermis layers of the skin. 


\section{Treatment of cutaneous wound}

The first AlGaInP laser irradiation at $5 \mathrm{~J} / \mathrm{cm}^{2}$, AlGaInP at $8 \mathrm{~J} / \mathrm{cm}^{2}$ and the application of HF occurred 24 hours after the injury for groups 2, 3 and 4, respectively. The animals of subgroup A (euthanized on day 7) received their treatment corresponding to five times, while the animals of Subgroup B (euthanized on day 14) received 11 times, both applied daily, once a day in consecutive days. The animals were accommodated in polypropylene cages and maintained during the whole experiment in good conditions of hygiene, temperature and illumination, and fed on standard diet of the vivarium, food (Labina ${ }^{\mathrm{TM}}$ ) and water "ad libitum".

The study was carried out using a low power laser AlGaInP (Laserpulse Ibramed) with a continuous wavelength of $660 \mathrm{~nm}, 30 \mathrm{~mW}$ power, scan mode within the area of the cutaneous wound and with a contact area of $0.06310 / \mathrm{cm}^{2}$. The High Frequency generator used for ozone generation was Ibramed HF - High Frequency Machine Facial Treatments, technique of sparking with cautery electrode (monopolar) inside the cutaneous wound area, maximum amplitude range, $50 / 60 \mathrm{~Hz}, 15 \mathrm{VA}$. The calibrated equipment was acquired by the researcher and used for the first time in this experiment.

The euthanasia of the animals happened on the $7^{\text {th }}$ and $14^{\text {th }}$ days, when there was the removal of the tissue for histological, histomorphometric and macroscopic analyzes. The mice were submitted to euthanasia by an overdose of sodium thiopental in the concentration of $50 \mathrm{mg} / \mathrm{kl}$.

\section{Macroscopic analysis}

The areas of the injuries were registered immediately after its production, seven and 14 days of treatment through a Nikon digital camera COOLPIX L820, resolution of 16 Megapixels, fixed on a tripod, kept at a constant distance of $30 \mathrm{~cm}$ from the surgical area. For the determination of the wound area and image analysis, the ImageJ software was used to calculate the area of the same.

\section{Histological and histomorphometric analysis}

The surgical specimen was removed immediately after the animal euthanasia, with a margin of $1 \mathrm{~cm}$ of skin around the lesion. Starting with the material fixed in $10 \%$ formalin, the histological technique of routine was processed, including the steps of gradual dehydration, diaphanization, infiltration and embedment in paraffin.

The samples were submitted to longitudinal histological cuts, stained with hematoxylin eosin (HE) and Masson trichromic and analyzed by microscope Olympus CX31, with $\mathrm{x} 400$ magnification. A qualitative histological analysis of inflammatory reaction was made, defined by: reepithelization, granulation tissue, presence of inflammatory cells, fibroblasts, collagen deposition and neovascularization, according to criteria described in the literature ${ }^{22}$. The histomorphometric quantitative analysis included the differential count of the presence of inflammatory cells, fibroblasts and blood vessels through the ImageJ software.

\section{Statistical analysis}

The D'Agostino \& Pearson normality test was applied and the statistic treatment was obtained by paired comparison with the help of the parametric test One-Way Anova test post hoc Tukey. The data were normal and considered significant when $\mathrm{p}<0.05$, through the GraphPad Prism 5.0 program.

\section{Results}

As shown in Figure 1, the macroscopic analysis of the percentage regression for cutaneous wound in mice at seven and 14 days, Group 3 (Laser $5 \mathrm{~J} / \mathrm{cm}^{2} \mathrm{~cm}^{2}$ ) was the only statistically significant group when compared to the other groups on day 7 ; however, in Table 1, which shows a qualitative distribution of the results found in the histological analysis ${ }^{22}$, all groups showed a slight reepithelialization and, as to the granulation tissue, groups 2 (HF) and 4 (laser $8 \mathrm{~J} / \mathrm{cm}^{2}$ ) were found moderate and groups 1 (control) and 3 , intense.

At 14 days, the laser groups of $5 \mathrm{~J} / \mathrm{cm}^{2}$ and $8 \mathrm{~J} / \mathrm{cm}^{2}$ showed to be statistically higher for wound regression (Figure 1) compared to groups 1 and 2 and, considering Table 1, the reepithelialization of most part of the analyzed samples was moderate (except the group 3, which was discreet) and the granulation tissue remained predominantly moderate in the groups. That way, the results suggest that lower doses of LPL $\left(5 \mathrm{~J} / \mathrm{cm}^{2}\right)$ are more effective in the acute phase of the inflammatory process, while in the tissue repair remodeling phase, the laser was effective for both doses tested. 


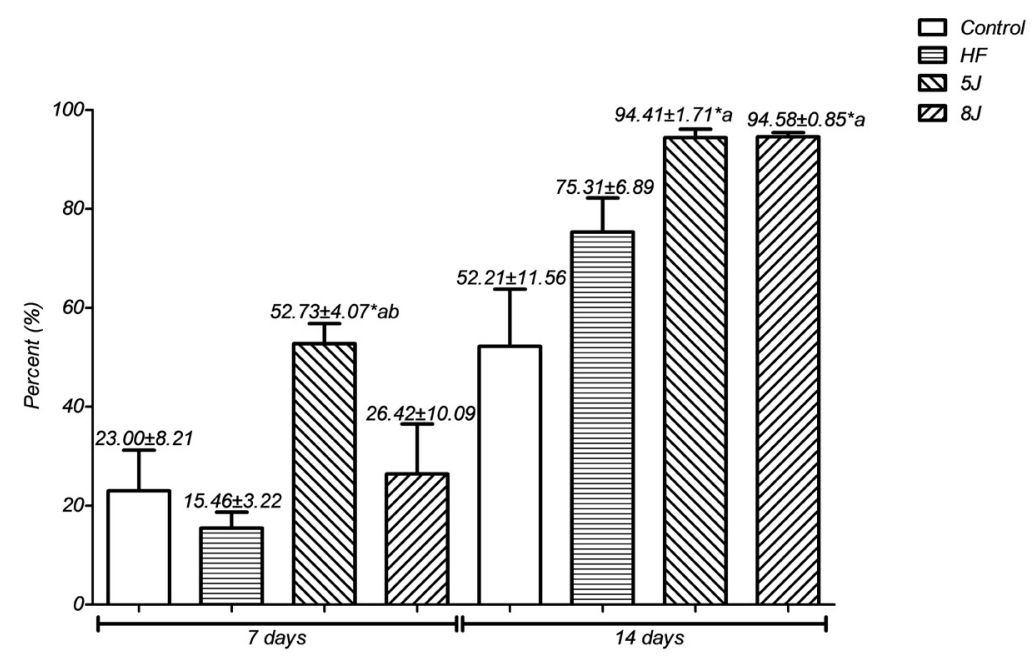

FIGURE 1 - Analysis of the percentage of the wound regression of different groups at 7 and 14 days. Data groups were compared with an analysis of variance (ANOVA) followed by Tukey's multiple comparison tests.

**: significance in relation to the control group; a: statistical significance in comparison to HF group and b: statistical significance in comparison to the Laser group at $8 \mathrm{~J} / \mathrm{cm}^{2}$.

In Figures 2, 3 and 4, we obtained the histomorphometric analysis related to, respectively, the number of vessels, the presence of fibroblasts and inflammatory cells present in the different groups at 7 and 14 days.

Figure 2 shows that at seven days, Group 2 received a significantly higher amount of blood vessels than Group 3, though for the qualitative distribution of histological analysis (Table 1) the HF group (group 2) has had a moderate formation of neovascularization and the laser at $5 \mathrm{~J} / \mathrm{cm}^{2}$ (group 3) has been intense, which may be related to the fact that literature ${ }^{16}$ suggests very large intervals for histological analysis criteria. At 14 days the statistically significant results were shown in the comparison of laser groups, where the one which had employed higher doses, in this case, $8 \mathrm{~J} / \mathrm{cm}^{2}$ (group 4), proved to be more relevant histomorphometrically, yet, in the qualitative distribution of histological analysis (Table 1) all groups showed an intense neovascularization.

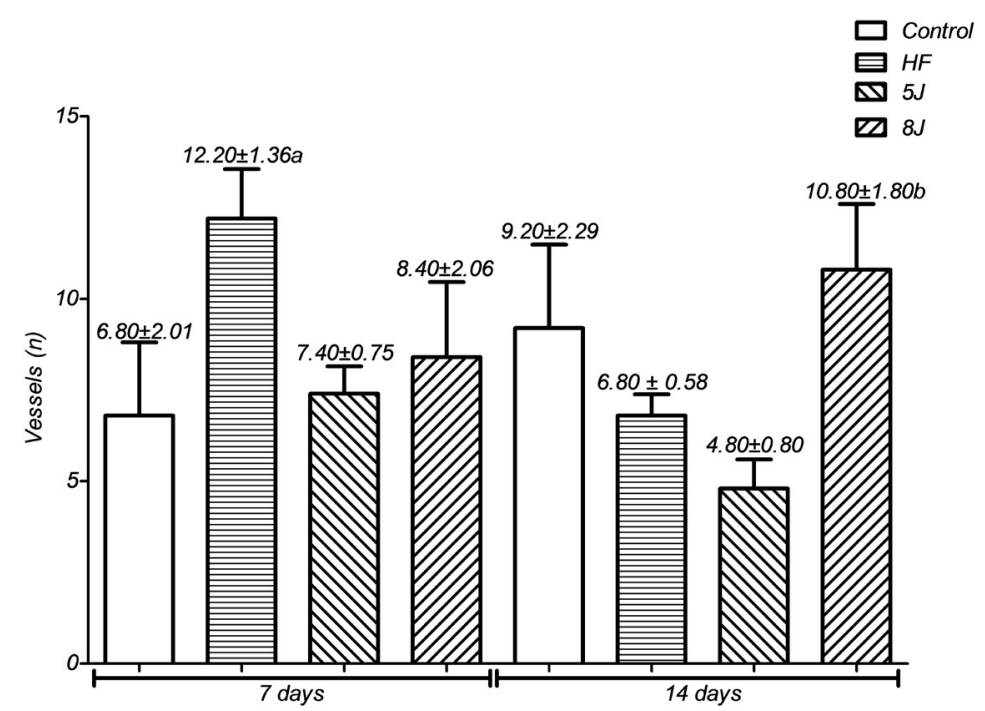

FIGURE 2 - Histomorphometric analysis of the number of vessels present in the different groups at 7 and 14 days. Data Groups were compared with an analysis of variance (ANOVA) followed by Tukey's multiple comparison tests.

a: significance of the HF in relation to laser $5 \mathrm{~J} / \mathrm{cm}^{2}$; b: significance of the laser $8 \mathrm{~J} / \mathrm{cm}^{2}$ in relation to laser $5 \mathrm{~J} / \mathrm{cm}^{2}$. 
TABLE 1 - Summary of results for the histological analysis (\%) at 7 and 14 days.

\begin{tabular}{|c|c|c|c|c|c|c|c|c|c|c|c|c|}
\hline \multicolumn{13}{|c|}{ Criteria } \\
\hline & \multicolumn{3}{|c|}{ Control } & \multicolumn{3}{|c|}{$\mathrm{HF}$} & \multicolumn{3}{|c|}{ Laser 5J } & \multicolumn{3}{|c|}{ Laser 8J } \\
\hline & $\mathrm{D}$ & M & I & $\mathrm{D}$ & M & I & $\mathrm{D}$ & M & I & $\mathrm{D}$ & M & I \\
\hline & \multicolumn{12}{|c|}{7 days } \\
\hline Reepithelization & 100 & - & - & 100 & - & - & 100 & - & - & 100 & - & - \\
\hline Acute inflammation & - & - & 100 & - & 100 & - & - & - & 100 & - & - & 100 \\
\hline Chronic inflammation & - & 100 & - & - & 100 & - & 100 & - & - & - & 100 & - \\
\hline Mixed inflammation & - & - & 100 & - & 100 & - & - & - & 100 & - & - & 100 \\
\hline Granulation tissue & - & - & 100 & - & 100 & - & - & - & 100 & - & 100 & - \\
\hline Neovascularization & - & - & 100 & - & 100 & - & - & - & 100 & - & - & 100 \\
\hline Fibroblasts & - & 100 & - & - & 100 & - & - & 100 & - & - & 100 & - \\
\hline \multirow[t]{2}{*}{ Collagen fibers } & 100 & - & - & 100 & - & - & 100 & - & - & 100 & - & - \\
\hline & \multicolumn{12}{|c|}{14 days } \\
\hline Reepithelization & - & 80 & 20 & 40 & 60 & - & 80 & 20 & - & 20 & 60 & 20 \\
\hline Acute inflammation & - & 40 & 60 & - & - & 100 & - & - & 100 & - & 20 & 80 \\
\hline Chronic inflammation & 40 & 60 & - & 100 & - & - & 100 & - & - & 100 & - & - \\
\hline Mixed inflammation & - & 80 & 20 & - & - & 100 & - & - & 100 & - & 20 & 80 \\
\hline Granulation tissue & - & 80 & 20 & - & 100 & - & - & 100 & - & - & 100 & - \\
\hline Neovascularization & - & - & 100 & - & - & 100 & - & - & 100 & - & - & 100 \\
\hline Fibroblasts & - & 60 & 40 & - & 100 & - & - & 100 & - & - & 100 & - \\
\hline Collagen fibers & - & 80 & 20 & 60 & 40 & - & 20 & 80 & - & 20 & 80 & - \\
\hline
\end{tabular}

Legend: $\mathrm{D}=$ Discrete, $\mathrm{M}=$ Moderate e $\mathrm{I}=$ Intense.

Concerning the histomorphometric analysis of the proliferation of fibroblasts (Figure 3), at 7 days all groups were effective compared to control group, especially group 4 , whose results were very significant. Similar results were found in the histological analysis, where all groups found moderate presence of fibroblasts, including the control group, with a discreet presence of collagen fibers.

At 14 days only Group 3 showed statistically higher values than Group 1. Nonetheless, it should be observed that in group 4, there was a higher visible reduction in the average of fibroblasts / field between seven and 14 days because it fell from \pm 185.80 to \pm 147.60 , which suggests that there was a bigger stimulus to maturation of fibroblasts proliferated in collagen for this group with higher doses of LPL irradiation $\left(8 \mathrm{~J} / \mathrm{cm}^{2}\right)$ compared to others. Table 1 also showed this tendency to maturation of collagen fibers at 14 days, which went from discreet to moderate in most of the samples analyzed in almost all groups.

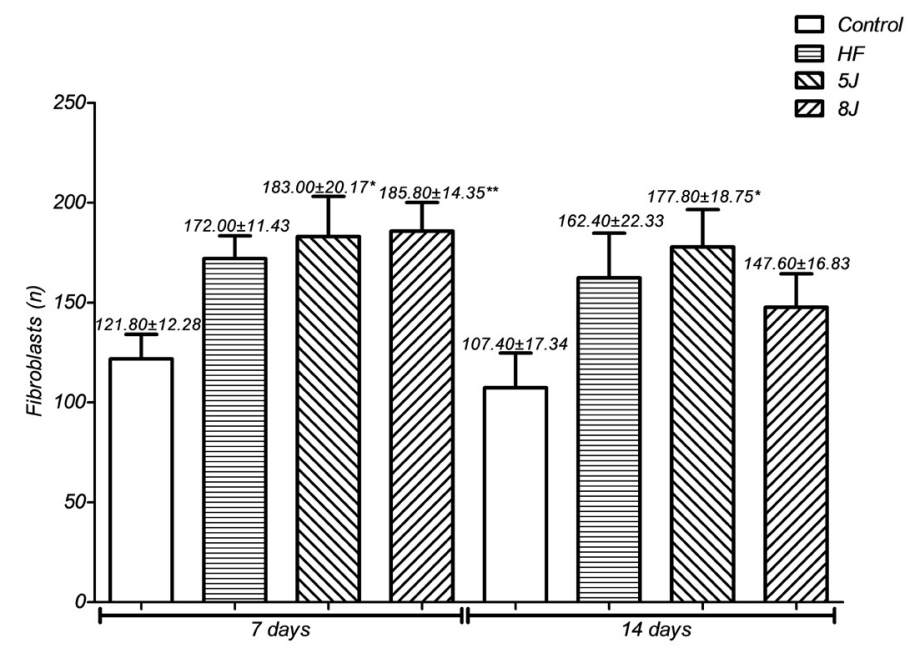

FIGURE 3 - Histomorphometric analysis of the fibroblasts quantity present in the different groups at 7 and 14 days. Groups of data were compared with an analysis of variance (ANOVA) followed by Tukey's multiple comparison tests.

*: significant results in relation to control group; ** very significant results in relation to control group. 
Regarding the presence of inflammatory cells (Figure 4), the histomorphometric analysis of the 7 days revealed that the HF groups and Laser groups at $5 \mathrm{~J} / \mathrm{cm}^{2}$ were more effective in reducing inflammation in acute phase of cicatrization than the LPL at higher doses. Although it did not obtain a significant result compared to control, on average, group 2 was the one that most shortened the inflammatory process in the early phase of the tissue cicatrization.

Similarly, in the histological analysis, at seven days, only the group that received treatment with HF showed acute and moderate mixed inflammation, while for all other groups it showed to be intense. Still considering this analysis, the laser group of $\mathrm{J} /$ $\mathrm{cm}^{2}$ was the one which had discreet chronic inflammation and the others, moderate.

At 14 days there were no significant results, but the lowest average for inflammatory cells was found in the Laser group at $5 \mathrm{~J} / \mathrm{cm}^{2}$, as well as the greater reduction of the amount of inflammatory cells between seven and 14 days found in the Laser Group at $8 \mathrm{~J} / \mathrm{cm}^{2}$, which changed from $48.80 \pm 4.89$ to $30.80 \pm$ 5.23 inflammatory / field cells. However, unlike the tendency of other groups, that on average showed a reduction in this parameter between 7 and 14 days, there was an increase in the HF group because the quantity of inflammatory cells / field went from 20.00 \pm 4.27 to $35.20 \pm 6.91$.

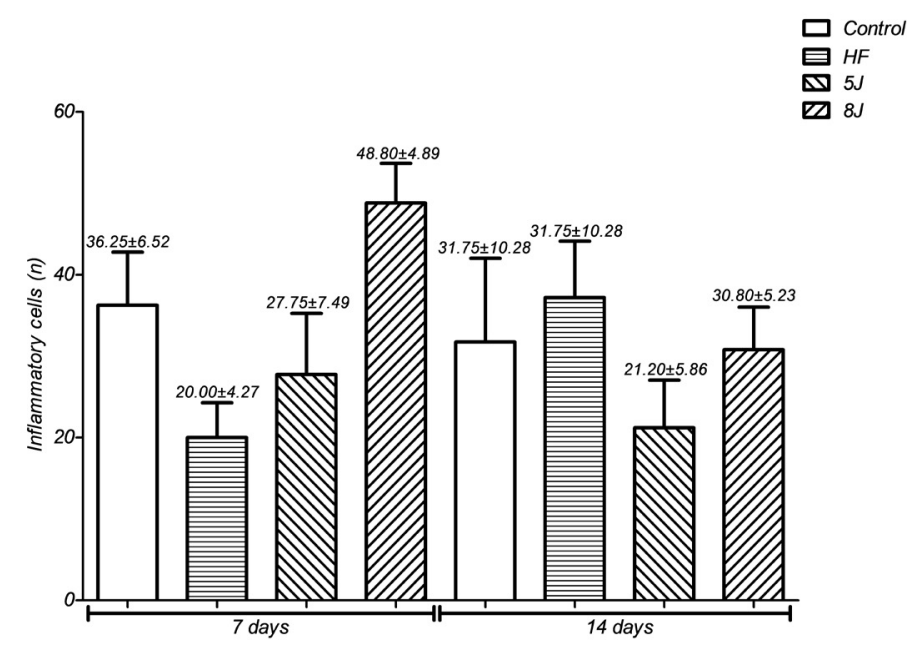

FIGURE 4 - Histomorphometric analysis of the inflammatory cells quantity present in the different groups at 7 and 14 days. Groups of data were compared with an analysis of variance (ANOVA) followed by Tukey's multiple comparison tests.

a and b: presence of inflammatory cells statistically superior in relation to the HF and the Laser of $5 \mathrm{~J} / \mathrm{cm}^{2}$, respectively.

According to Table 1, Group 2, at 14 days, went from a moderate inflammation to an intense acute and mixed inflammation, what most of the other groups had since seven days. The histological analysis of chronic inflammation was discreet for all groups, including the laser $5 \mathrm{~J} / \mathrm{cm}^{2}$, which was thus kept since the seven days of treatment (except for control group, of which most samples kept moderate chronic inflammation).

\section{Discussion}

Studies suggest that LPL, as well as HF, facilitate tissue repair of cutaneous wounds, ${ }^{7,9,12,16,19-21}$. Similar results, especially in relation to the laser, were found in this study. Although the HF did not display a good efficacy in the comparative analysis of this study, it is known to play a beneficial role in the dehiscence of surgical wounds ${ }^{16}$ and pressure ulcers ${ }^{9}$, since the aid in the treatment of the cutaneous lesions and infected dermatological lesions is associated with its confirmed antiseptic and bactericidal action $^{23}$.

In another research ${ }^{24}$, which compared the treatment of HF (amplitude range of 80\%, small Standard electrode 120s) with the LPL (AlGaInP, $670 \mathrm{~nm}, 30 \mathrm{~mW}, 6 \mathrm{~J} / \mathrm{cm}^{2}$, 1 point, 120s) and the combined therapy of both, the HF, as well as the LPL, showed significant results in the regression of the wound $(\mathrm{p}<0.05)$; the combination therapy was even more significant $(\mathrm{p}<0.01)$. In comparison to this study (Figure 1), in the same range of days evaluated, only the Laser group at $5 \mathrm{~J} / \mathrm{cm}^{2}$ was effective, after seven days of incisional injury, although with different doses and application mode.

Positive effects of the LPL $(630 \mathrm{~nm})$ also have been found in the initial and middle phases of the healing process of cutaneous wounds in diabetic mice ${ }^{25}$ by a dose of $3.6 \mathrm{~J} / \mathrm{cm}^{2}$ compared in different powers: $5 \mathrm{~mW} / \mathrm{cm}^{2}(12 \mathrm{~min}), 10 \mathrm{~mW} / \mathrm{cm}^{2}$ (6 $\mathrm{min}$ ) and $20 \mathrm{~mW} / \mathrm{cm}^{2}$ (3 $\mathrm{min}$ ), applied five times / week for two weeks. It was observed that all laser groups promoted significant results in wound contraction in relation to the control group on the $3^{\text {rd }}, 6^{\text {th }}$ and $9^{\text {th }}$ day of treatment, but none on the $12^{\text {th }}$ day.

It is observed that the low dosage used in the aforementioned study was effective only in the initial phase of wound healing when compared to control group. The present study (Figure 1), which used higher doses and power of LPL, also presented significant laser results in lower dose in the acute phase of wound cicatrization and, in both doses, the lowest and the highest, in the remodeling phase, probably because the higher doses of LPL are more efficient in the remodeling phase than in the acute phase.

Regarding the microscopic findings, a study with similar variables ${ }^{26}$ also proved satisfactory performance of AlGaInP laser for the burns healing treatment, because the semiquantitative histological analysis, after 10 days, showed that LPL (660 nm, 
precise, continuous mode, $30 \mathrm{~mW}, 10 \mathrm{~J} / \mathrm{cm}^{2}$ for 9 seconds/point inside the burning in six points and $12 \mathrm{~J} / \mathrm{cm}^{2}$ for 11 seconds/point in the wound edge in 14 points) promoted a significant proliferation of fibroblasts, collagen, new vessels and cutaneous annexes.

Similar to such effect of LPL in burns ${ }^{26}$, in this study there was also a significant presence of histomorphometric fibroblasts for laser groups in relation to control group (Figure 3), as well as a strong presence of new vessels (at seven and 14 days) and moderate presence of collagen (at 14 days), as seen in the histological analysis of Table 1.

Another study ${ }^{7}$ showed that the LPL (InGaAlP, $660 \mathrm{~nm}$, $4 \mathrm{~J} / \mathrm{cm}^{2}, 660 \mathrm{~nm}$ for 24 seconds) has a positive influence on the percentage of collagen and macrophages in cutaneous wounds, increasing the average amount of collagen fibers and reducing the macrophages fibers. However, in this study none of laser groups showed lower quantities of inflammatory cells when compared to the control group in a statistically significant form. The group in which higher doses of laser were applied, achieved a significant higher amount of inflammatory cells compared to other treatment groups analyzed, probably because smaller LPL doses are more effective to reduce inflammation in the acute phase of cicatrization.

In a research using the LPL AsGa (904 nm with peak power of $15 \mathrm{~mW}$ ) in oxidative parameters (the respiratory chain enzymes) in wound cicatrization with 18 rats, randomly divided into three groups (control 5 days, 5 days $/ 2 \mathrm{~J} / \mathrm{cm}^{2}, 5$ days $/ 4 \mathrm{~J} / \mathrm{cm}^{2}$ ), submitted to one single circular wound of $8 \times 8 \mathrm{~mm}$ in the mouse's dorsum, it was concluded that the laser stimulates antioxidant activity thus protecting cells against oxidative damage during the process of cicatrization for cutaneous wounds in rats ${ }^{12}$.

According to literature, doses ranging from 3-6 J/cm² appear to be more effective, while doses higher than $10 \mathrm{~J} / \mathrm{cm}^{2}$ are associated with harmful effects ${ }^{13}$, nevertheless, it was proved that a daily dose of $30 \mathrm{~J} / \mathrm{cm}^{2}$ and power density at $25 \mathrm{~mW} / \mathrm{cm}^{2}$ of 670 $\mathrm{nm}$ laser, continuous mode, was able to shorten the inflammation without compromising the metabolism of fibroblasts, positively influencing all the phases of wound cicatrization in the skin of 49 rats, which produced two parallel wounds on the back, where one served as a control and the other was exposed to laser irradiation ${ }^{21}$.

In a study ${ }^{25}$ that compared the LPL irradiation at a dose of $3.6 \mathrm{~J} / \mathrm{cm}^{2}$ in different powers: $5 \mathrm{~mW} / \mathrm{cm}^{2}(12 \mathrm{~min}), 10 \mathrm{~mW} /$ $\mathrm{cm}^{2}$ (6 $\mathrm{min}$ ) and $20 \mathrm{~mW} / \mathrm{cm}^{2}$ (3 $\left.\mathrm{min}\right)$, applied 5 times/week for two weeks, showed that, generally the larger laser irradiation powers were more effective and significant for the quality of the cicatrization process, according to some histological criteria, such as collagen synthesis, proliferation of fibroblasts, epithelialization, quantity of polymorphonuclear and neovascularization.
In general, it is observed that in the literature there is no consensus about the ideal parameters for the application of LPL on cutaneous wounds, however, it is known that its biological effect depends on three ideal parameters: wavelength, dosing, and power density $^{21}$.

\section{Conclusions}

Low power laser was more effective at $5 \mathrm{~J} / \mathrm{cm}^{2}$ than at $8 \mathrm{~J} / \mathrm{cm}^{2}$ in the acute phase of the cicatrization process. For the remodeling phase, both doses presented relevant results and laser at $8 \mathrm{~J} / \mathrm{cm}^{2}$ presented more significant results at 14 days than at seven days, suggesting that in the initial phase of the cicatrization process, lower doses are more effective, whereas in the more advanced phase, higher doses will bring more stimuli to tissue regeneration.

As to the HF, although it did not present the same efficacy as the LPL, its performance was also more effective in the initial phase of cicatrization. However, for further conclusions about the effectiveness of this resource in the cutaneous wound cicatrization process, more studies are recommended to know about the factors that affect the process of repair for these tissues.

\section{References}

1. Carneiro MIS. Ribas Filho JM, Malafaia O, Ribas CAPM, Santos CAM, Cavalcanti TCS, Czeczko LEA. Estudo comparativo do uso de extrato de Pfaffia glomerata e do laser de baixa potência (HélioNeônio) na cicatrização de feridas em ratos. ABCD Arq Bras Cir Dig. 2010;23(3):163-7. doi: 10.1590/S0102-67202010000300007.

2. Isaac C, Rego FMP, Ladeir PRS, Altram SC, Oliveira RC, Aldunate JLCB, Paggiaro AO, Ferreira MC. Construction of a skin substitute composed of porcine collagen matrix populated with human dermal fibroblasts and keratinocytes: histological evaluation. Rev Bras Cir Plast. 2012;27(4):503-8. doi: 10.1590/S1983-51752012000400004.

3. Ferreira MC, Paggiaro AO, Isaac C, Teixeira Neto N, Santos GB. Skin substitutes: current concepts and a new classification system. Rev Bras Cir Plast. 2011;26(4):696-702. doi: 10.1590/S198351752011000400028.

4. Tacon KCB, Santos HCO, Parente LML, Cunha LC, Lino-Júnior RS, Ribeiro-Rotta RF, Tacon FSA, Amaral WN. Healing activity of laser InGaAlP (660 nm) in rats. Acta Cir Bras. 2011;26(5):373-8. doi: 10.1590/S0102-86502011000500008.

5. Mandelbaum SH, Di Santis EP, Mandelbaumm MH. Cicatrização: conceitos atuais e recursos auxiliares - Parte I. An Bras Dermatol. 2003;78(5):393-410. doi: 10.1590/S0365-05962003000400002.

6. Rezende AC, Luchesi C, Barbo MLP, Duek EAR. Membranas de poli (ácido lático-co-ácido glicolítico) como curativos para pele: degradação in vitro e in vivo. Polímeros. 2005;15(3):232-8. doi: 10.1590/S0104-14282005000300015.

7. Carvalho PTC, Silva IS, Reis FA, Pereira DM, Aydos RD. Influence of InGaAlP laser $(660 \mathrm{~nm})$ on the healing of skin wounds in diabetic rats. Acta Cir Bras. 2010;25(1):71-9. PMID: 20126892.

8. Neves SMV, Nicolau RA, Maia Filho ALM, Mendes LMS, Veloso 
AM. Digital photogrammetry and histomorphometric assessment of the effect of non-coherent light (light-emitting diode) therapy $(640 \pm 20 \mathrm{~nm})$ on the repair of third-degree burns in rats. Lasers Med Sci. 2014;29:203-12. doi: 10.1007/s10103-013-1312-7.

9. Korelo RIG, Oliveira JJJ, Souza RSA, Hullek RF, Fernandes LC. Gerador de alta frequência como recurso para tratamento de úlceras por pressão: estudo piloto. Fisioter Mov. 2013;26(4):715-24. doi: 10.1590/S0103-51502013000400002.

10. Martins M, Maia Filho ALM, Costa CLS, Coelho NPMF, Costa MS, Carvalho RA. Anti-inflammatory action of the Ovis aries lipidic fraction associated to therapeutic ultrasound in an experimental model of tendinits in rats (Rattus norvegicus). Rev Bras Fisioter. 2011;15(4):297-302. doi: 10.1590/S1413-35552011000400007.

11. Rocha Júnior AM, Oliveira RG, Farias RE, Andrade LCF, Aarestrup FM. Modulação da proliferação fibroblástica e da resposta inflamatória pela terapia a laser de baixa intensidade no processo de reparo tecidual. An Bras Dermatol. 2006;81(2):150-6. doi: 10.1590/ S0365-05962006000200006.

12. Silveira PCL, Silva LA, Tuon T, Freitas TP, Streck EL, Pinho RA. Efeitos da laserterapia de baixa potência na resposta oxidativa epidérmica induzida pela cicatrização de feridas. Rev Bras Fisioter. 2009;13(4):281-7. doi: 10.1590/S1413-35552009005000040.

13. Andrade FSSD, Clark RMO, Ferreira ML. Efeitos da laserterapia de baixa potência na cicatrização de feridas cutâneas. Rev Col Bras Cir. 2014;41(2):129-33. doi: 10.1590/S0100-69912014000200010.

14. Fukuda TY, Malfatti CA. Análise da dose do laser de baixa potência em equipamentos nacionais. Rev Bras Fisioter. 2008;12(1):70-4. doi: 10.1590/S1413-35552008000100013.

15. Lins RDAU, Dantas EM, Lucena KCR, Catão MHCV, GranvilleGárcia AF, Carvalho Neto LG. Efeito bioestimulante do laser de baixa potência no processo de reparo. An Bras Dermatol. 2010;85(6):849-55. doi: 10.1590/S0365-05962010000600011.

16. Tacani PM, Toguch PAPM, Machado AFP, Tacani RE, Freitas JOG. Prevalência e tratamento de fisioterapêutico de deiscências da ferida operatória após cirurgias plásticas: análise retrospectiva. Rev Bras Ciênc Saúde. 2014;12(39):28-34. doi: 10.13037/rbcs. vol12n39.2110.

17. Dogan M, Dogan DO, Duger C, Kol IO, Akpinar A, Mutaf B, Akar T. Effects of high-frequency bio-oxidative ozone therapy in temporomandibular disorder-related pain. Med Princ Pratc. 2014;23:507-10. doi: 10.1159/000365355.

18. Silva JLM, Doimo G, Faria DP. Uso de ondas de alta frequência no tratamento de onicomicose - comunicação preliminar de três casos. An Bras Dermatol. 2011;86(3):598-600. doi: 10.1590/S036505962011000300033.

19. Busnardo VL, Biondo-Simões MLP. Os efeitos do laser de hélioneônio de baixa intensidade na cicatrização de lesões cutâneas induzidas em ratos. Rev Bras Fisioter. 2010;14(1):45-51. doi: 10.1590/S1413-35552010000100008.
20. Dal Agnol MA, Nicolau RA, Lima CJ, Munin E. Comparative analysis of coherent light action (laser) versus non-coherent light (light-emitting diode) for tissue repair in diabetic rats. Lasers Med Sci. 2009;24(4):909-16. PMID: 19238507.

21. Gál P, Vidinský B, Toporcer T, Mocrý M, Mozes S, Longauer F, et al. Todos os autores. Histological assessment of the effect of laser irradiation on skin wound healing in rats. Photomed Laser Surg. 2006;24(4):480-8. PMID: 16942428.

22. Meirelles GC, Santos JN, Chagas PO, Moura AP, Pinheiro AL. A comparative study of the effects of laser photobiomodulation on the healing of tird-degree burns -a histological study in rats. Photomed Laser Surg. 2008;26(2):159-66. PMID: 18338966.

23. Martins A, Silva JT, Graciola L, Fréz AR, Ruaro JÁ, Marquetti MGK. Efeito bactericida do gerador de alta frequência na cultura de Staphylococcus aureus. Rev Fisioter Pesq. 2012;19(2):153-7. doi: 10.1590/S1809-29502012000200011.

24. Sá HP, Nunes HM, Santo LAE, Oliveira Júnior GC, Silva JMN, Carvalho KC, et al. Todos os autores. Estudo comparativo da ação do laser GalInP e do gerador de alta frequência no tratamento de feridas cutâneas em ratos: estudo experimental. ConScientiae Saúde. 2010;9(3):360-6.

25. Ma H, LI Y, Chen H, Kang M, Liu C. Effects of low-intensity laser irradiation on wound healing in diabetic rats. Int $\mathrm{J}$ Photoenergy. 2012;1-7. doi: 10.1155/2012/838496.

26. Freitas RPA, Barcelos APM, Nóbrega BM, Macedo AB, Oliveira AR, Ramos AMO, et al. Todos os autores. Laserterapia e microcorrentes na cicatrização de queimaduras em ratos. Terapias associadas ou isoladas? Fisioter Pesq. 2013;20(1):24-30. doi: 10.1590/S180929502013000100005.

\section{Correspondence:}

Rayssilane Cardoso de Sousa

Praça da Liberdade, 1753

64000-040 Teresina - PI Brasil

rayssilane14@hotmail.com

Received: Aug 08, 2015

Review: Oct 10, 2015

Accepted: Nov 12, 2015

Conflict of interest: none

Financial source: none

${ }^{1}$ Research performed at Fisiology Laboratory, Faculdade Integral Diferencial (FACID/DeVry), Teresina-PI, Brazil. 